\title{
Breast Cancer Treatment in the Era of Molecular Imaging
}

\author{
Gundula Edelhauser Martin Funovics
}

Workgroup for Experimental Radiology and Preclinical Imaging, Cardiovascular and Interventional Radiology, Department of Radiology, Medical University of Vienna, Austria

\section{Key Words}

Breast cancer - Molecular imaging - PET - MRI . Optical imaging $\cdot$ Receptor

\section{Summary}

Molecular imaging employs molecularly targeted probes to visualize and often quantify distinct disease-specific markers and pathways. Modalities like intravital confocal or multiphoton microscopy, near-infrared fluorescence combined with endoscopy, surface reflectance imaging, or fluorescence-mediated tomography, and radionuclide imaging with positron emission tomography (PET) and single-photon emission computed tomography (SPECT) are increasingly used for small animal high-throughput screening, drug development and testing, and monitoring gene therapy experiments. In the clinical treatment of breast cancer, PET and SPECT as well as magnetic resonance-based molecular imaging are already established for the staging of distant disease and intrathoracic nodal status, for patient selection regarding receptor-directed treatments, and to gain early information about treatment efficacy. In the near future, reporter gene imaging during gene therapy and further spatial and qualitative characterization of the disease can become clinically possible with radionuclide and optical methods. Ultimately, it may be expected that every level of breast cancer treatment will be affected by molecular imaging, including screening.

\section{Schlüsselwörter}

Brustkrebs · Molekulare Bildgebung - PET · MRT .

Optische Bildgebung · Rezeptor

\section{Zusammenfassung}

Molekulare Bildgebung verwendet auf bestimmte Moleküle gerichtete Sonden, um bestimmte krankheitsspezifische Marker und Stoffwechselwege zu visualisieren und oft auch zu quantifizieren. Modalitäten wie die intravitale konfokale oder Multiphotonenmikroskopie, die Fluoreszenzbildgebung im nahen Infrarot, entweder als oberflächengewichtete Reflexionsbildgebung, als Endoskopie, oder als Fluoreszenz-mediierte Tomographie, und Isotopenbildgebung mit Positronenemissionstomographie (PET) und Single-Photon-Emissionstomographie (SPECT) werden in immer größerem Ausmaß für Kleintiere genutzt. Die Anwendungen umfassen Selektionierungen mit hohem Durchsatz, Medikamentenentwicklung und die Beobachtung von Gentherapieexperimenten. In der klinischen Behandlung von Brustkrebs sind PET und SPECT sowie Magnetresonanz-basierende molekulare Bildgebung bereits für das Staging von Fernmetastasen und für den intrathorakalen Lymphknotentatus etabliert, sowie für die Patientenselektion hinsichtlich Rezeptorgerichteter Therapien und um frühe Informationen über die Effektivität einer Behandlung zu erlangen. In der nahen Zukunft können die Bildgebung von Reportergenen während der Gentherapie und weitere räumliche und qualitative Charakterisierung der Erkrankung mit isotopenbasierten und optischen Methoden klinisch möglich werden. Letztlich kann erwartet werden, dass jede Ebene der Brustkrebsbehandlung von molekularer Bildgebung beeinflusst wird, einschließlich des Screenings.

\section{KARGER}

Fax +497614520714

Information@Karger.de

www.karger.com (c) 2008 S. Karger GmbH, Freiburg

Accessible online at:

www.karger.com/brc

Doz. Dr. Martin Funovics

Abteilung für Kardiovaskuläre und Interventionelle Radiologie, $8 \mathrm{~F}$

Universitätsklinik für Radiodiagnostik

Medizinische Universität Wien

Währinger Gürtel 18-20, 1090 Wien, Austria

martin.funovics@meduniwien.ac.at 


\section{Introduction}

Current concepts of clinical diagnosis and treatment are increasingly influenced by the continuous progress in cellular and molecular biology techniques. The understanding of the molecular mechanisms underlying many pathologic processes, the capability to decipher and translate whole genomes, the identification of a multitude of receptors, enzymes and other molecules as effectors for targeted diagnosis and therapy have altered our understanding and management of disease today. Over the past 2 decades, imaging has played an ever increasing role in these processes by bridging the gap between new methods discovered at the bench on a molecular or cellular level and their direct, non-destructive visualization in a living macroscopic organism. Consequently, molecular imaging has become a rapidly emerging and heavily funded research discipline. While there is (and will be) no entirely satisfying definition discriminating it from 'morphologic' or 'physiologic' imaging, most authors agree that molecular imaging comprises the visualization (and often quantification) of biologic processes at the cellular or subcellular level by defined molecular interactions of an imaging probe with a target [1,2].

Traditionally, imaging was aimed at visualization of anatomic (e.g. tumor) or physiologic (e.g. hypervascularization) changes to identify pathologies or to assess reaction to treatment. Such changes, however, occur only as late manifestations of the cellular and molecular alterations causing the disease. The visualization of these early changes would allow for earlier detection and intervention at a stage where the result is more likely and easily influenced [3]. A number of different imaging modalities are currently used in the treatment of breast cancer in oncologic research or in the clinical setting.

\section{Radionuclide Imaging Modalities}

The two main modalities for molecular imaging using radioactive isotopes are single-photon emission computed tomography (SPECT), and positron emission tomography (PET). In SPECT, a rotating gamma camera visualizes a single high-energy photon from a gamma emitter. In PET, a coincidence camera visualizes only pairs of high-energy photons travelling in opposite directions which have been created by the annihilation of a positron from a beta ${ }^{+}$emitter and an electron from the surrounding matter. PET can more easily be corrected for the attenuation effects of the surrounding tissue and is about an order of magnitude more sensitive than SPECT, mainly because of the lack of collimators which are inherently necessary for SPECT imaging.

The most common form of molecular PET imaging employs a labeled glucose analog, ${ }_{18}$ fluorodeoxyglucose (FDG). This molecule is actively transported into the cell by the Glut- 1 glucose transporter where it is irreversibly phosphorylated by hexokinase, trapping it within the cell where it does not pro-

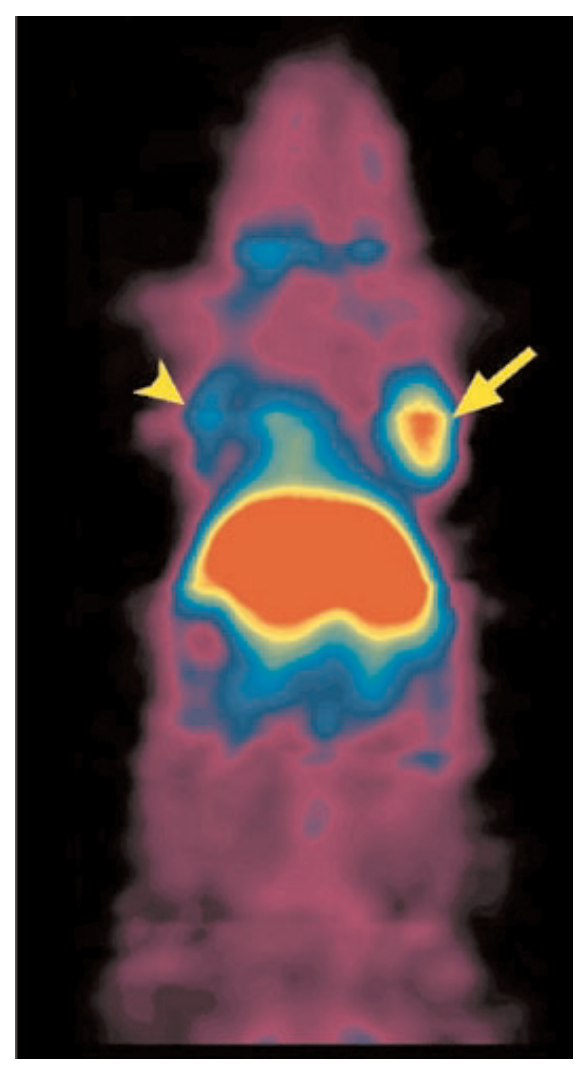

Fig. 1. Micro-PET image of a mouse injected with $26 \mu \mathrm{Ci}$ of a ${ }^{64} \mathrm{Cu}$-labelled anti-CEA minibody. Note the uptake in the CEA-positive tumor in the left shoulder (arrow), while no significant uptake occurs in the CEA-negative control tumor in the right shoulder (arrowhead). Unspecific uptake occurs in the liver. Adapted, with permission, from [53].

ceed further down the glycolytic pathway. The glucose transporter is overexpressed in many cancers including breast cancer, resulting in increased FDG uptake compared to normal tissue. [4].

In other approaches, several intra- and extracellular proteins (enzymes or receptors) [5] have been targeted, mostly with either radiolabeled ligands (fig. 1) or substrates that change their membrane permeability upon interaction with a target enzyme [6,7]. While extracellular targets face less penetration barriers and therefore the probes have more favorable pharmacokinetics, the reaction product with intracellular targets is less likely to interact with the immune system and more likely to locally accumulate $[1,8]$. In addition, the interaction with an enzyme can provide an important amplification step because enzymes can repeatedly react with multiple substrate molecules $[5-7,9]$.

\section{Magnetic Resonance Imaging}

Magnetic resonance (MR) imaging visualizes the relaxation time of hydrogen atoms, mainly in body water, in a static magnetic field. This time is altered by the chemical environment of the hydrogen atom (native imaging), and by local irregularities of the magnetic field, induced by the presence of paramagnetic or superparamagnetic substances (contrast-enhanced imaging). Compared to radionuclide imaging, MR imaging offers higher spatial resolution and limited sensitivity. Consequently, a high- 

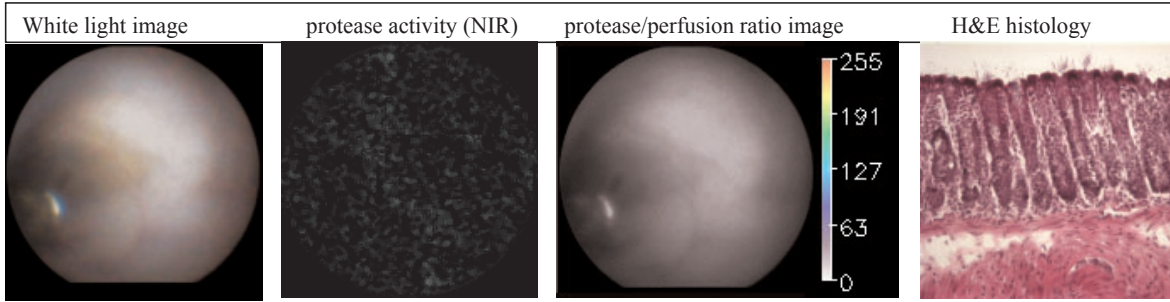

Fig. 2. In vivo mouse colonoscopy. In the first row, normal colon is shown. Neither in the NIR channel nor by ratio imaging a signal is detected. Second row, small APC $\mathrm{Min}^{++}$adenoma, 3rd row, large $\mathrm{APC}^{\mathrm{Min} /+}$ adenoma, 4th row, invasive cancer. The NIR channel shows constantly areas of high signal intensity and high signalto-background ratio corresponding to the areas of neoplasia. Ratio imaging shows moderately elevated values for small adenoma with moderate dysplasia, markedly elevated values for large adenoma with severe dysplasia, and high values for invasive cancer. The corresponding $\mathrm{H}$ and $\mathrm{E}$ sections demonstrate adenomatous formations with moderate or high dysplasia and tumoral invasion of the muscular layer. Adapted, with permission, from [21].
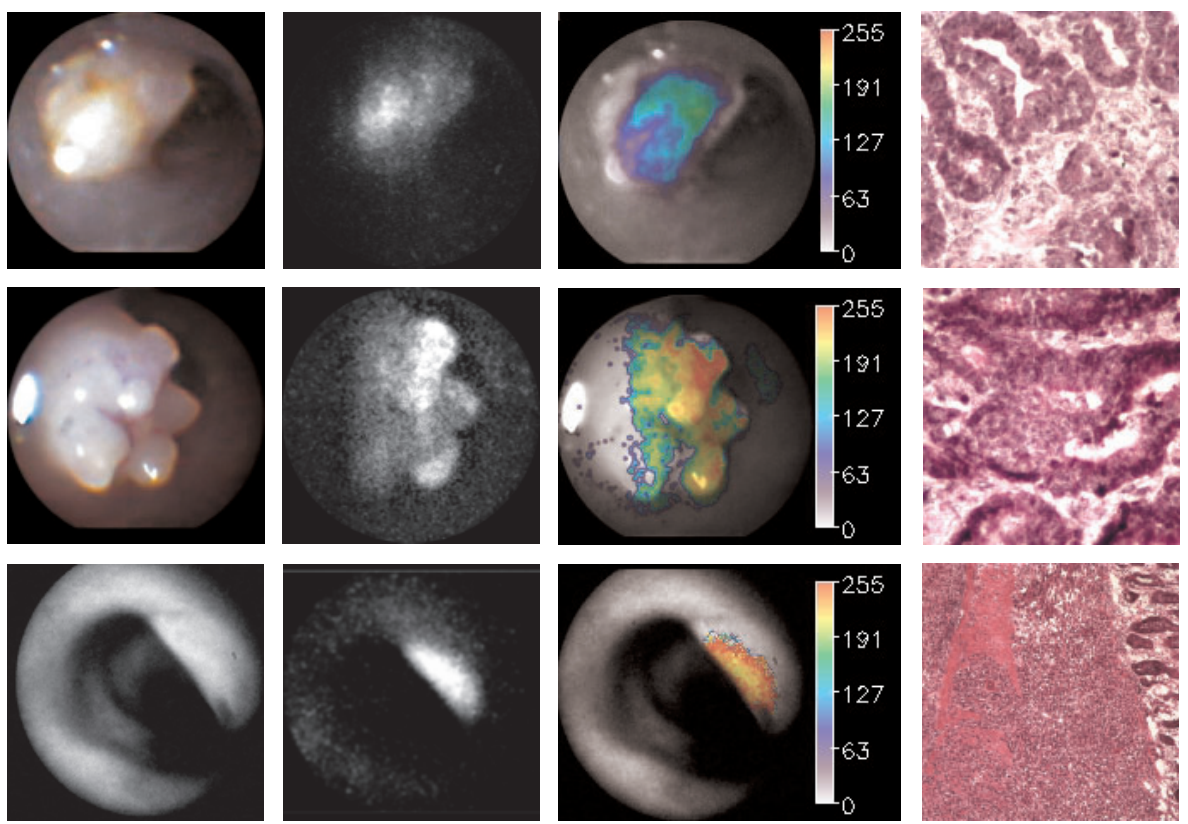

er molar concentration of the molecular imaging probe is necessary for efficient detection in the target tissue [10]. Usually, amplification strategies have to be incorporated into the design of a MR molecular imaging probe. This can be accomplished by targeting a receptor which undergoes endocytosis and receptor recycling upon interaction with the probe, thereby accumulating the probe in the cytoplasm [11]. A different approach is to employ a superparamagnetic nanoparticle, with between 20 and 50 binding sites per particle [12]. These sites can then be bound to antibodies, minibodies, or peptide fragments with a known high affinity to a cell membrane target [13]. By multivalent attachment, the probe reaches a dysproportionally higher affinity to the target, thereby achieving a higher concentration [1].

\section{Optical Imaging Modalities}

Optical imaging visualizes bioluminescence or differences in absorption, reflection, or fluorescence of tissues. Newer techniques used in molecular optical imaging include diffuse optical tomography [14], molecular endoscopy, and intravital microscopy with confocal $[15,16]$ or multiphoton imaging [17-19].

Due to the absorption of light in living tissue, optical imaging methods generally suffer from limited penetration depths cur- rently in the order of 1-10 cm. While a human whole-body optical imaging system will not be available in the foreseeable future, optical imaging is routinely practiced in small animals such as mice and rats [20]. In addition, proof-of-concept for minimally invasive approaches with fiberoptic systems or intraoperative applications exists. While some optical imaging methods such as fluorescence-mediated tomography are inherently quantitative, optical imaging offers the unique capability of a multichannel approach. By simultaneously imaging at 2 or more wavelengths, different probes can be visualized at the same time. This concept was used to determine the presence and at the same time to quantify the degree of dysplasia in precancerous and cancerous lesions in the murine colon in vivo (fig. 2) [21, 22].

The advent of probes that are optically silent and only become fluorescent upon interaction with one specific enzyme has considerably increased the signal-to-noise ratios by avoiding the enormous amount of unspecific signal during the application of the probe, which is common in most other imaging modalities [23].

\section{Molecular Imaging in Breast Cancer Therapy}

In the past years, new treatments have been developed that prolong survival, induce remission, and provide better quality 

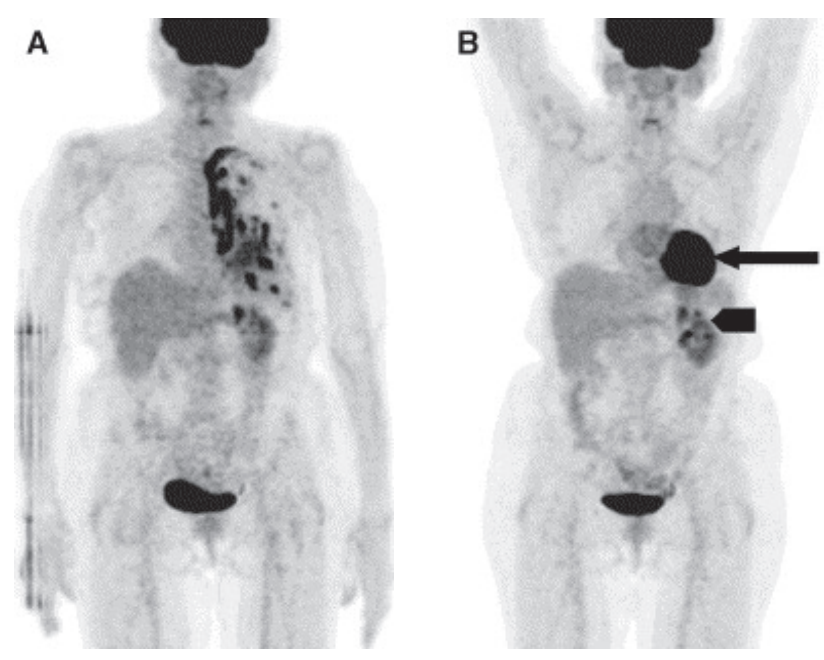

Fig. 3. Maximum-intensity projection of ans FDG-PET scan with extensive left pleural involvement A before and $\mathbf{B}$ after 1 dose of fulvestrant, with resolved pleural uptake. Note unspecific cardiac uptake (arrow). Adapted, with permission, from [4].

of life for cancer patients [24]. The earliest studies on the use of FDG-PET in the diagnosis of breast cancer were in 1989 [25]. Since then, FDG-PET imaging has become the dominant molecular imaging modality for breast cancer, demonstrating its worth with advanced-stage disease, determining response to therapy, and in cases of suspected recurrent and metastatic involvement (fig. 3) [4, 26].

\section{Axillary Node Staging}

In the clinical setting, several studies have compared conventional MR imaging to FDG-PET in axillary lymph node staging. Generally, MR imaging showed higher sensitivity, and PET showed higher specificity in the detection of axillary nodal disease. This is due to the lower spatial resolution of PET, and the missed foci were correspondingly below $15 \mathrm{~mm}$ in size [27]. While there seems to be consensus that FDG-PET alone is not yet sensitive enough to allow the avoidance of axillary node dissection (AND) in negative studies [28], potentially the combination of sentinel node biopsy with FDG-PET may prove to have enough sensitivity for this purpose.

Optical imaging using near-infrared fluorescent (NIRF) macromolecular probes administered either intravenously or intracutaneously has given promising results in lymph node detection in the animal model [29]. However, due to its limited depth penetration, NIRF will likely have to be used in conjunction with endoscopic approaches or during partial dissection in human applications.

\section{Staging Distant Disease}

Contrary to its limited role in axillary staging, FDG-PET has been shown to be consistently superior to conventional imag- ing modalities in staging of mediastinal, internal mammary, and distant disease [30-32] both in sensitivity and in specificity. In whole-body lymph node staging, the application of lymphotropic superparamagnetic nanoparticles with subsequent whole-body MR imaging has yielded excellent sensitivity and specificity in the detection of renal and prostate cancer metastases [33-35]. This concept can likely be transferred to breast cancer patients in the near future.

\section{Molecular Imaging of the Estrogen Receptor}

Hormonal therapy is one of the earliest and still most important targeted therapies of breast cancer. The estrogen receptor (ER) is up-regulated in most breast cancers, and halting the receptor-triggered cell proliferation is associated with tumor regression [36]. Current therapeutic concepts aim at either receptor blockade (tamoxifen), induction of ER down-regulation (fulvestrant), or by lowering ligand concentration (aromatase inhibitors) [37].

Since low or absent ER expression predicts a low likelihood of therapeutic response [38], molecular ER imaging could primarily function in directing hormonal therapy to receptor-positive tumors. A substantial percentage of patients with an ERpositive primary tumor can have one or more sites of ER-negative metastatic disease [39], thus, a complete ER status cannot be provided by biopsy in multicentric disease. A recent calculation assuming a hypothetical diagnostic algorithm including molecular ER imaging in the decision for hormonal therapy could double response rates without withholding appropriate therapy to potential responders [40].

Currently, no approved agent for PET ER imaging exists, but several compounds have been investigated [37]. Quantitative results correlating with in-vitro assays have been achieved with 16-fluoroestradiol-17 $\beta$, an estrogen analog [41].

\section{Molecular Imaging in Breast Cancer Research}

Perhaps the most important potential contribution of molecular imaging in breast cancer treatment is to affect therapy by visualizing and quantifying fundamental tumor cell processes such as proliferation, apoptosis, angiogenesis, and hypoxia [24].

\section{Angiogenesis Imaging}

Angiogenesis, the tumor-driven formation of new vessels by the host, is a fundamental prerequisite for tumor growth and metastatic spread [42]. Several receptors are up-regulated by endothelial cells during angiogenesis, and have been visualized with a receptor-targeted approach. The alpha(v)beta(3) integrin $\left(\alpha_{V} \beta_{3}\right)$ has been targeted with nanoparticles linked to peptides with the R-G-D motif or conjugated to antibodies [43]. Such conjugates have also been effective in localizing melanoma micrometastases in mice [44]. Endothelial selectin, which is up-regulated in inflammation and tumor angiogene- 
sis, has been successfully imaged in a similar approach using an optically active nanoparticle conjugated to a peptide sequence with high affinity to the receptor [45].

\section{Apoptosis Imaging}

Apoptosis or programmed cell death is as important as cell proliferation in the development, regeneration, and homeostasis of an organism. Carcinogenesis is as much a breakdown of apoptotic mechanisms as it is a result of growth stimulation [46]. In addition, the development of blocks in the apoptotic signal cascade is the main reason why tumors develop resistance to chemo- and radiotherapy [47, 48]. A marker for apoptosis is annexin $\mathrm{V}$, a protein that binds to externalized membrane components characteristic for apoptotic cells. It has long been used in histopathology, and recently, the feasibility of radionuclide $[49,50]$ and optical in-vivo imaging of apoptosis has been demonstrated [51].

\section{Gene Therapy Imaging}

In cancer treatment, gene therapy is aimed at the introduction or alteration of the cellular genome in the target tissue in an effort to either correct specific genetic alterations, to induce tumor cell death, or to provide a point of attack for targeted therapies. Experiments have been conducted on suppression of oncogenic products, alterations of receptor expression [52, 53], activation of apoptosis or tumor suppressor genes [54-56]. In a phase I clinical trial, a viral transcriptional regulator was introduced into cancer cells by a liposomal delivery system and has been shown to effectively target and repress tumoral ErbB-2 overexpression and induce apoptosis [57].

Reporter gene imaging has formed a substantial part of gene therapy from its beginning. Briefly, the vector which introduces the therapeutic gene also includes a gene whose protein product is expressed under the same promotor and in the same location and concentration as the therapeutic gene. It can be visualized in a molecular imaging modality, thereby helping to determine the efficiency of transfection, and the amount and location of the transfected tissue. Such reporter genes typically include luciferase for visualization by bioluminescence [58], or an intracellular enzyme which converts a prodrug which is able to cross the cell membrane into the active imaging probe which can not pass the membrane and accumulates in the cell. Prodrugs include radiolabeled uracil nucleoside derivatives or acylguanosine derivatives, which can be phosphorylated by the HSV-thymidine kinase [53].

A different approach of gene therapy termed molecular chemotherapy aims at introducing effective pathways for drug delivery into the tumor via receptor expression or the induction of intracellular enzymes [52]. These products can then be visualized by MR imaging, near-infrared fluorescence, or fluorescence-mediated tomography [9].

An inherent problem with gene therapy is that each cellular transfection in itself has no effect on the surrounding tissue, thus, the majority of the tumor cells must be transfected for a clinical effect. Molecular imaging can potentially aid in the refinement of such protocols.

\section{Conclusion}

In the near future, we anticipate a growing availability and prevalence of molecular imaging techniques in breast cancer therapy. FDG-PET is already established as an effective clinical tool for the staging of intrathoracic and distant disease, while it can not yet replace sentinel node biopsy or axillary dissection. Whole-body ER imaging may be superior to biopsy in selecting patients for hormonal treatment, and radionuclide and MR-based modalities will aid in the monitoring of clinical studies of gene therapy. In laboratory research, optical imaging provides a high-throughput modality for drug development and monitoring of therapeutic efficacy. It can be expected that methods of molecular imaging, probably with optical probes, will ultimately even provide reliable screening tools for breast cancer.

\section{References}

1 Weissleder R, Mahmood U: Molecular imaging. Radiology 2001;219:316-333.

2 Weissleder R, Pittet MJ: Imaging in the era of molecular oncology. Nature 2008;452:580-589.

3 Cai W, Gambhir SS, Chen X: Chapter 7. Molecular imaging of tumor vasculature. Methods Enzymol 2008;445:141-176.

4 Schuster DM, Halkar RK: Molecular imaging in breast cancer. Radiol Clin North Am 2004;42 885-908, vi-vii.

5 Gambhir SS, Barrio JR, Phelps ME, Iyer M, Namavari M, Satyamurthy N, Wu L, Green LA, Bauer E, MacLaren DC, Nguyen K, Berk AJ, Cherry SR, Herschman HR: Imaging adenoviral-directed reporter gene expression in living animals with positron emission tomography. Proc Natl Acad Sci U S A 1999;96:2333-2338.
6 Saito Y, Price RW, Rottenberg DA, Fox JJ, Su TL, Watanabe KA, Philips FS: Quantitative autoradiographic mapping of herpes simplex virus encephalitis with a radiolabeled antiviral drug. Science 1982;217:1151-1153.

7 Tjuvajev JG, Stockhammer G, Desai R, Uehara H, Watanabe K, Gansbacher B, Blasberg RG: Imaging the expression of transfected genes in vivo. Cancer Res 1995;55:6126-6132.

8 Bogdanov A Jr, Petherick P, Marecos E, Weissleder $\mathrm{R}$ : In vivo localization of diglycylcysteine-bearing synthetic peptides by nuclear imaging of oxotechnetate transchelation. Nucl Med Biol 1997;24: 739-742.

9 Shah K, Jacobs A, Breakefield XO, Weissleder R: Molecular imaging of gene therapy for cancer. Gene Ther 2004;11:1175-1187.
10 Weissleder R, Moore A, Mahmood U, Bhorade R, Benveniste H, Chiocca EA, Basilion JP: In vivo magnetic resonance imaging of transgene expression. Nat Med 2000;6:351-355.

11 Funovics MA, Kapeller B, Hoeller C, Su HS, Kunstfeld R, Puig S, Macfelda K: MR imaging of the Her2/neu and 9.2.27 tumor antigens using immunospecific contrast agents. Magn Reson Imaging 2004;22:843-850.

12 Montet X, Funovics M, Montet-Abou K, Weissleder R, Josephson L: Multivalent effects of RGD peptides obtained by nanoparticle display. J Med Chem 2006;49:6087-6093.

13 Weissleder R, Kelly K, Sun EY, Shtatland T, Josephson L: Cell-specific targeting of nanoparticles by multivalent attachment of small molecules. Nat Biotechnol 2005;23:1418-1423. 
14 Ntziachristos V, Yodh AG, Schnall M, Chance B: Concurrent MRI and diffuse optical tomography of breast after indocyanine green enhancement. Proc Natl Acad Sci U S A 2000;97:2767-2772.

15 Korlach J, Schwille P, Webb WW, Feigenson GW Characterization of lipid bilayer phases by confocal microscopy and fluorescence correlation spectroscopy. Proc Natl Acad Sci U S A 1999;96: 8461-8466.

16 Rajadhyaksha M, Grossman M, Esterowitz D, Webb RH, Anderson RR: In vivo confocal scanning laser microscopy of human skin: melanin provides strong contrast. J Invest Dermatol 1995;104: 946-952.

17 Buehler C, Kim KH, Dong CY, Masters BR, So PT: Innovations in two-photon deep tissue microscopy. IEEE Eng Med Biol Mag 1999;18:23-30.

18 Dellian M, Yuan F, Trubetskoy VS, Torchilin VP, Jain RK: Vascular permeability in a human tumour xenograft: molecular charge dependence. Br J Cancer 2000;82:1513-1518.

19 Monsky WL, Fukumura D, Gohongi T, Ancukiewcz M, Weich HA, Torchilin VP, Yuan F, Jain RK: Augmentation of transvascular transport of macromolecules and nanoparticles in tumors using vascular endothelial growth factor. Cancer Res 1999;59: 4129-4135.

20 Niedre MJ, de Kleine RH, Aikawa E, Kirsch DG, Weissleder R, Ntziachristos V: Early photon tomography allows fluorescence detection of lung carcinomas and disease progression in mice in vivo. Proc Natl Acad Sci U S A 2008, Epub ahead of print.

21 Funovics M, Weissleder R, Tung CH: Protease sensors for bioimaging. Anal Bioanal Chem 2003;377: 956-963.

22 Boxerman JL, Hamberg LM, Rosen BR, Weisskoff RM: MR contrast due to intravascular magnetic susceptibility perturbations. Magn Reson Med 1995;34:555-566.

23 Weissleder R, Tung CH, Mahmood U, Bogdanov A $\mathrm{Jr}$ : In vivo imaging of tumors with protease-activated near-infrared fluorescent probes. Nat Biotechnol 1999;17:375-378.

-24 Kelloff GJ, Krohn KA, Larson SM, Weissleder R, Mankoff DA, Hoffman JM, Link JM, Guyton KZ, Eckelman WC, Scher HI, O'Shaughnessy J, Cheson BD, Sigman CC, Tatum JL, Mills GQ, Sullivan DC, Woodcock J: The progress and promise of molecular imaging probes in oncologic drug development. Clin Cancer Res 2005;11:7967-7985.

25 Minn H, Soini I: [18f]fluorodeoxyglucose scintigraphy in diagnosis and follow up of treatment in advanced breast cancer. Eur J Nucl Med 1989;15: 61-66.

26 Margolis DJ, Hoffman JM, Herfkens RJ, Jeffrey RB, Quon A, Gambhir SS: Molecular imaging techniques in body imaging. Radiology 2007;245: 333-356.

27 Walter C, Scheidhauer K, Scharl A, Goering UJ, Theissen P, Kugel H, Krahe T, Pietrzyk U: Clinical and diagnostic value of preoperative MR mammography and FDG-PET in suspicious breast lesions. Eur Radiol 2003;13:1651-1656.

28 Guller U, Nitzsche E, Moch H, Zuber M: Is positron emission tomography an accurate non-invasive alternative to sentinel lymph node biopsy in breast cancer patients? J Natl Cancer Inst 2003;95: 1040-1043.
29 Josephson L, Mahmood U, Wunderbaldinger P, Tang Y, Weissleder R: Pan and sentinel lymph node visualization using a near-infrared fluorescent probe. Mol Imaging 2003;2:18-23.

30 Bellon JR, Livingston RB, Eubank WB, Gralow JR, Ellis GK, Dunnwald LK, Mankoff DA: Evaluation of the internal mammary lymph nodes by FDGPET in locally advanced breast cancer (LABC). Am J Clin Oncol 2004:27:407-410.

31 Eubank WB, Mankoff DA, Takasugi J, Vesselle H, Eary JF, Shanley TJ, Gralow JR, Charlop A, Ellis GK, Lindsley KL, Austin-Seymour MM, Funkhouser CP, Livingston RB: 18fluorodeoxyglucose positron emission tomography to detect mediastinal or internal mammary metastases in breast cancer. J Clin Oncol 2001;19:3516-3523.

$32 \mathrm{Wu}$ D, Gambhir SS: Positron emission tomography in diagnosis and management of invasive breast cancer: current status and future perspectives. Clin Breast Cancer 2003;4(suppl 1):S55-63.

33 Guimaraes AR, Tabatabei S, Dahl D, McDougal WS, Weissleder R, Harisinghani MG: Pilot study evaluating use of lymphotrophic nanoparticle-enhanced magnetic resonance imaging for assessing lymph nodes in renal cell cancer. Urology 2008;71: 708-712.

34 Harisinghani MG, Weissleder R: Sensitive, noninvasive detection of lymph node metastases. PLoS Med 2004;1:e66.

35 Harisinghani MG, Barentsz J, Hahn PF, Deserno WM, Tabatabaei S, van de Kaa CH, de la Rosette J, Weissleder R: Noninvasive detection of clinically occult lymph-node metastases in prostate cancer. N Engl J Med 2003;348:2491-2499.

36 Sledge GW Jr, McGuire WL: Steroid hormone receptors in human breast cancer. Adv Cancer Res 1983;38:61-75.

37 Katzenellenbogen BS, Frasor J: Therapeutic targeting in the estrogen receptor hormonal pathway. Semin Oncol 2004;31:28-38.

38 Campbell FC, Blamey RW, Elston CW, Morris AH, Nicholson RI, Griffiths K, Haybittle JL: Quantitative oestradiol receptor values in primary breast cancer and response of metastases to endocrine therapy. Lancet 1981;2:1317-1319.

39 Gutierrez MC, Detre S, Johnston S, Mohsin SK, Shou J, Allred DC, Schiff R, Osborne CK, Dowsett M: Molecular changes in tamoxifen-resistant breast cancer: relationship between estrogen receptor, Her-2, and p38 mitogen-activated protein kinase. J Clin Oncol 2005;23:2469-2476.

40 Linden HM, Stekhova SA, Link JM, Gralow JR, Livingston RB, Ellis GK, Petra PH, Peterson LM, Schubert EK, Dunnwald LK, Krohn KA, Mankoff DA: Quantitative fluoroestradiol positron emission tomography imaging predicts response to endocrine treatment in breast cancer. J Clin Oncol 2006;24:2793-2799.

41 Mintun MA, Welch MJ, Siegel BA, Mathias CJ, Brodack JW, McGuire AH, Katzenellenbogen JA: Breast cancer: PET imaging of estrogen receptors. Radiology 1988;169:45-48.

42 Folkman J: Role of angiogenesis in tumor growth and metastasis. Semin Oncol 2002;29:15-18.

43 Chen X, Park R, Shahinian AH, Tohme M, Khankaldyyan V, Bozorgzadeh MH, Bading JR, Moats R, Laug WE, Conti PS: 18f-labeled RGD peptide: initial evaluation for imaging brain tumor angiogenesis. Nucl Med Biol 2004;31:179-189.
44 Schmieder AH, Winter PM, Caruthers SD, Harris TD, Williams TA, Allen JS, Lacy EK, Zhang H, Scott MJ, Hu G, Robertson JD, Wickline SA, Lanza GM: Molecular MR imaging of melanoma angiogenesis with alphanubeta3-targeted paramagnetic nanoparticles. Magn Reson Med 2005;53:621-627.

45 Funovics M, Montet X, Reynolds F, Weissleder R, Josephson L: Nanoparticles for the optical imaging of tumor e-selectin. Neoplasia 2005;7:904-911.

6 Hajra KM, Liu JR: Apoptosome dysfunction in human cancer. Apoptosis 2004;9:691-704.

47 Hersey P, Zhang XD: Overcoming resistance of cancer cells to apoptosis. J Cell Physiol 2003;196: 9-18.

48 Knudson AG: Cancer genetics. Am J Med Genet 2002;111:96-102.

49 Belhocine T, Steinmetz N, Hustinx R, Bartsch P, Jerusalem G, Seidel L, Rigo P, Green A: Increased uptake of the apoptosis-imaging agent $(99 \mathrm{~m})$ tc recombinant human annexin $\mathrm{v}$ in human tumors after one course of chemotherapy as a predictor of tumor response and patient prognosis. Clin Cancer Res 2002;8:2766-2774.

50 Kemerink GJ, Liu X, Kieffer D, Ceyssens S, Mortelmans L, Verbruggen AM, Steinmetz ND, Vanderheyden JL, Green AM, Verbeke K: Safety, biodistribution, and dosimetry of 99mtc-hynic-annexin $\mathrm{v}$ a novel human recombinant annexin $\mathrm{v}$ for human application. J Nucl Med 2003;44:947-952.

51 Gee MS, Upadhyay R, Bergquist H, Weissleder R, Josephson L, Mahmood U: Multiparameter noninvasive assessment of treatment susceptibility, drug target inhibition and tumor response guides cancer treatment. Int J Cancer 2007;121:2492-2500.

52 Ruppert JM, Wright M, Rosenfeld M, Grushcow J, Bilbao G, Curiel DT, Strong TV: Gene therapy strategies for carcinoma of the breast. Breast Cancer Res Treat 1997;44:93-114.

53 Berger F, Gambhir SS: Recent advances in imaging endogenous or transferred gene expression utilizing radionuclide technologies in living subjects: applications to breast cancer. Breast Cancer Res 2001; 3:28-35.

54 Boxhorn HK, Eck SL: Gene therapy for breast cancer. Hematol Oncol Clin North Am 1998;12: 665-675.

55 Phillips HA: The role of the p53 tumour suppressor gene in human breast cancer. Clin Oncol (R Coll Radiol) 1999;11:148-155.

56 Wang NP, To H, Lee WH, Lee EY: Tumor suppressor activity of rb and p53 genes in human breast carcinoma cells. Oncogene 1993;8:279-288.

57 Hung MC, Hortobagyi GN, Ueno NT: Development of clinical trial of e1a gene therapy targeting Her-2/neu-overexpressing breast and ovarian cancer. Adv Exp Med Biol 2000;465:171-180.

58 Chen IY, Greve JM, Gheysens O, Willmann JK, Rodriguez-Porcel M, Chu P, Sheikh AY, Faranesh AZ, Paulmurugan R, Yang PC, Wu JC, Gambhir SS Comparison of optical bioluminescence reporter gene and superparamagnetic iron oxide MR contrast agent as cell markers for noninvasive imaging of cardiac cell transplantation. Mol Imaging Biol 2008, Epub ahead of print. 